ppi $201502 Z U 4645$

Esta publicación cientifica en formato digital es continuidad de la revista impresa ISSN-Versión Impresa 0798-1406 / ISSN-Versión on line 2542-3185Depósito legal pp

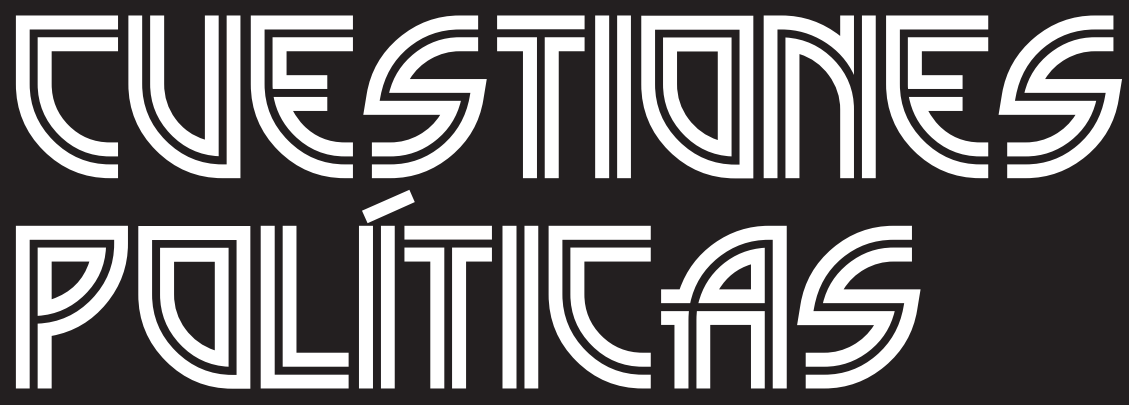

Instituto de Estudios Políticos y Derecho Público "Dr. Humberto J. La Roche' de la Facultad de Ciencias Jurídicas y Políticas de la Universidad del Zulia Maracaibo, Venezuela
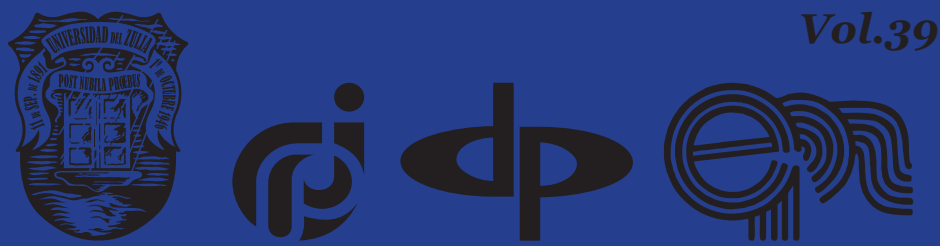


\title{
Assessment of Business Infrastructure in 2018
}

\author{
DOI: https://doi.org/10.46398/cuestpol.3968.24
}

\author{
Iuliia S. Pinkovetskaia * \\ Anton V. Lebedev ** \\ Mikhail A. Rozhkov *** \\ Natalia V. Berezina ****
}

\begin{abstract}
The aim of the research is to assess development of entrepreneurship infrastructure of various countries according to opinions of experts from these countries. The elements were: knowledge and technology transfer infrastructure; commercial and professional infrastructure; production and information infrastructure; market infrastructure; institutions providing easy access to existing markets; social and cultural infrastructure. The research is based on methods of economic analysis, analogies, generalizations, classification, system and structural approaches. Information from the Global entrepreneurship monitoring project report for 54 countries was used as input data. The estimation of the distribution of indicator values on the effectiveness of the six main infrastructure elements of business development reflecting the opinions of experts from these countries with the use of mathematic models of normal distribution. During the study we determined the average indicator values characterizing experts ' opinions on the effectiveness of each of the six key infrastructure elements of business development on a scale of ten; the intervals of their changes characteristic for the majority of countries were also considered. New knowledge about the effectiveness of infrastructure elements of business development in various countries has been obtained.
\end{abstract}

Keywords: enterprise infrastructure; economic policy; entrepreneurship; small and medium-sized enterprises; global monitoring of entrepreneurship.

* PhD, Associate Professor, Department of Economic analysis and state management, Ulyanovsk State University, Ulyanovsk, Russia. ORCID ID: https://orcid.org/oooo-0002-8224-9031. Email: pinkovetskaia@gmail.com

** PhD, Associate Professor, the Department of Foreign Languages, National Research Ogarev Mordovia State University, Saransk, Russia. ORCID ID: https://orcid.org/oooo-0002-1927-5595. Email: toshaleb@mail.ru

** PhD, Associate Professor, the Department of Foreign Languages, National Research Ogarev Mordovia State University, Saransk, Russia. ORCID ID: https://orcid.org/oooo-0002-9001-5497. Email: mikha-rozhkov@yandex.ru

****PhD, Associate Professor, Department of Finance, Credit and Economic Security, Chuvash State University, Cheboksary, Russia. ORCID ID: https://orcid.org/oooo-ooo1-7320-3624. Email: bernav@ yandex.ru 


\section{Evaluación de Infraestructura Empresarial en 2018}

\section{Resumen}

El objetivo de la investigación es evaluar el desarrollo de la infraestructura empresarial de varios países de acuerdo con las opiniones de expertos internacionales. Los elementos en consideración fueron: infraestructura de transferencia de conocimiento y tecnología; infraestructura comercial y profesional; infraestructura de producción e información; infraestructura de mercado; instituciones que faciliten el acceso a los mercados existentes; infraestructura social y cultural. La investigación se basa en métodos de análisis económico, analogías, generalizaciones, clasificación, enfoques sistémicos y estructurales. Se utilizó como datos de entrada información del informe del proyecto de seguimiento de la iniciativa empresarial mundial para 54 países. La estimación de la distribución de los valores de los indicadores sobre la efectividad de los seis principales elementos de infraestructura del desarrollo empresarial reflejando las opiniones de los expertos de estos países con el uso de modelos matemáticos de distribución normal. Durante el estudio, determinamos los valores promedio de los indicadores que caracterizan las opiniones de los expertos sobre la efectividad de cada uno de los seis elementos clave de la infraestructura del desarrollo empresarial en una escala de diez; También se consideraron los intervalos de sus cambios característicos de la mayoría de países.

Palabras clave: infraestructura empresarial; política económica; emprendimiento; pequeñas y medianas empresas; monitoreo global del emprendimiento.

\section{Introduction}

The development of entrepreneurship is based in most countries on improving competitiveness (Pinkovetskaia et al., 2020), economic growth (De Carolis and Saparito, 2006; Kiseleva et al., 2019), reducing unemployment, evolving new markets, perfecting people life (Decker et al., 2014; Simon-Moya et al., 2016; Pinkovetskaia et al., 2019). Therefore, one of the most urgent problems solved at the state level in modern national economies is the formation of effective infrastructure elements that ensure the development of entrepreneurship. These infrastructure elements are a set of interconnected objects that serve business activities. These include organizations, enterprises, institutions, and other economic entities, structures, and economic and social systems. Most governments, especially those in developing countries, have made some effort and invested resources in these infrastructure elements of enterprise development. Business associations, universities and public organizations also play an essential function in this. 


\section{Literature review}

The relevance of the problem of creating and functioning of various types of infrastructure elements in modern national economies is reflected in scientific publications. Business entities generate a great part to the economic sector of their countries through the commercialization of research and development. Therefore, one of the most essential items of business at present is the transfer of knowledge and technology. Researcher Sung (2002) in his work considered the features of the process of innovation transfer in modern conditions. He suggested that there are four stages of knowledge and technologies transfer: their creation, exchange, implementation in the context of specific enterprises, and commercialization of innovations. In the article of Gunsel (2015) using the example of 33 Turkish firms, the effectiveness of information exchange and transfer of advanced technologies in developing countries is considered. Dickerhof (2010) drew attention to the need for huge expenditures on the development of technologies and equipment in the field of microsystem technology. Therefore, the opening firms in this industry requires corporations to share their technologies and applied achievements along with their knowledge.

Due to the small number of their teams, entrepreneurs are forced to outsource a number of functions. This includes such functions as accounting and reporting, legal and information and consulting services. Professional consultants are needed not only to help start and manage new businesses, but also to connect entrepreneurs with experts and support systems. This conclusion follows from the article by sh. Robinson and Stubberud (2014) and a research document of the World Bank (InfoDev, 2010).

The work of Obokoh and Goldman (2016) emphasizes the need to provide reliable infrastructure as a key factor in business sphere of countries. This study, based on an analysis of the situation in Nigeria, shows that the lack of production infrastructure negatively affects the performance of entrepreneurs who have to bear high costs for self-sufficiency in electricity and road rehabilitation on their own. The role of advanced information technologies in the activities of enterprises, including small ones, is significant. This is shown in article of Gare and Melin (2011), which examines communication and data transmission systems available in various countries and used by entrepreneurs. Calderon and Serven (2004) conducted a practical assessment of the influence of industrial sector on increase for 100 countries in the period from 1960 to 2000.

The features of small and medium enterprises in rapidly expanding regional markets of South, East and South-East Asia are considered by Vandenberg et al. (2016). This monograph shows the effectiveness of free and open markets where no business entity has the right to set prices, were changes in demand cause changes in supply and vice versa. A study by Kemp at al. (2003) discovers that exists 37 limits that can avoid firms from 
getting in the market, hindering the controversial process. Issues such as the size of barriers, their stability, and methods of measuring barriers are considered. The paper by Panayotis (2010) demonstrates that easy market entry increases supply, lowers prices, and intensifies innovation. This paper describes the 13 most important sources of regulatory barriers and assesses their role.

The results of research by Alvarez et al. (2011) and Gaganis et al. (2018) show that informal factors, namely norms in culture and social spheres, also the public image of businessmen have a significant impact on the development of entrepreneurship in the European Union.

\section{Methodology}

As a review of previous research shows, the main infrastructure elements that ensure the development of entrepreneurship in modern countries are:

- knowledge and technology transfer infrastructure.

- commercial and professional infrastructure.

- production and information infrastructure.

- market infrastructure.

- institutions that provide easy access to existing markets.

- social and cultural infrastructure.

The aim of our research was to assess the effectiveness of the main infrastructure elements of business development in various countries, according to experts from these countries. At the same time, the tasks of identifying countries with high and low levels of effectiveness of each of the main elements, as well as the medium indicators of the analyzed values and their intervals of change, typical for most of the countries under consideration, were solved.

Surveys of experts in various countries are devoted to studying the features of entrepreneurship in modern national economies, the results of which are combined in a General report on the Global entrepreneurship monitor project (2019). Our research based on the data of discussing report for 2018, reflecting the opinions of experts on the effectiveness of the main infrastructure elements of business development. For each country, the monitoring process identified the views of at least 36 highly qualified experts. Experts assessed the level of efficiency of the six infrastructure elements of entrepreneurship mentioned above on a ten-point scale. A value equal to 1 corresponded to a very low level of efficiency, while a value equal to 10 corresponded to a very high level. The average indicators for 
experts living in each country are presented in table 11 of the above report on the Global enterprise monitoring project.

This report provides data for 54 countries. It contains the opinions of experts from 21 European countries, 14 Asian countries, 11 Latin American countries, 6 African countries and 2 North American countries. Mentioned countries are distributed by income level as follows: 32 states have high incomes, 14 countries have medium incomes, and 8 countries have low incomes.

In the course of our research, we considered indicators that characterize the opinions of experts on the effectiveness of each of the six infrastructure elements of business development in all 54 countries.

Three hypotheses $(\mathrm{H})$ were checked in the process of our study:

- $\mathrm{H} 1$ - at the moment, there are great contrasts in the indicators that characterize the effectiveness of infrastructure elements of business development in the countries under consideration.

- H2 - stage in the income of population is not influence on maximum and minimum size of six indicators.

- H3 - territorial position of countries is not influence on maximum and minimum size of six indicators.

The checking of such hypothesis was made with mathematical modeling practical information on the base of density indicators of the countries (Pinkovetskaia, 2015). Elaborated models were consumed for establishment of parameters for approximating the practical data. During elaborating the mathematical models, we applied the practical information provided in table 11 of the Global enterprise monitoring.

\section{Results}

As indicated above, the assessment (on a ten-point scale) of the distribution of indicators that characterize expert opinions was based on the development of appropriate models that approximate the initial empirical data. The developed economic and mathematical models describing the patterns of regional distribution of performance indicators of the above six infrastructure elements of business development in 54 countries have the following form: 
390 Iuliia S. Pinkovetskaia, Anton V. Lebedev, Mikhail A. Rozhkov y Natalia V. Berezina Assessment of Business Infrastructure in 2018

- knowledge and technology transfer infrastructure

$y_{1}\left(x_{1}\right)=\frac{37.13}{0.96 \times \sqrt{2 \pi}} \cdot e^{\frac{-\left(x_{1}-4.39\right)^{2}}{2 \times 0.96 \times 0.96}} ;$

- for commercial and professional infrastructure

$y_{2}\left(x_{2}\right)=\frac{27.77}{0.78 \times \sqrt{2 \pi}} \cdot e^{\frac{-\left(x_{2}-5.46\right)^{2}}{2 \times 0.78 \times 0.78}} ;$

- on production and information infrastructure

$y_{3}\left(x_{3}\right)=\frac{46.29}{1.05 \times \sqrt{2 \pi}} \cdot e^{\frac{-\left(x_{3}-7.04\right)^{2}}{2 \times 1.05 \times 1.05}} ;$

- by market infrastructure

$$
y_{4}\left(x_{4}\right)=\frac{42.43}{1.04 \times \sqrt{2 \pi}} \cdot e^{\frac{-\left(x_{4}-5.77\right)^{2}}{2 \times 1.04 \times 1.04}} ;
$$

- for institutions that provide easy access to existing markets

$$
y_{5}\left(x_{5}\right)=\frac{32.38}{0.82 \times \sqrt{2 \pi}} \cdot e^{\frac{-\left(x_{5}-4.71\right)^{2}}{2 \times 0.82 \times 0.82}} ;
$$

- on social and cultural infrastructure

$$
y_{6}\left(x_{6}\right)=\frac{50.14}{1.13 \times \sqrt{2 \pi}} \cdot e^{\frac{-\left(x_{6}-5.39\right)^{2}}{2 \times 1.13 \times 1.13}} \text {. }
$$


Econometric analysis using Kolmogorov-Smirnov, Pearson, and Shapiro-Wilk checks demonstrated good quality level models (1)-(6).

\section{Discussion}

Applying the mathematical models (1)-(6), we achieved that were revealed indicator values that describes the opinions of experts on the effectiveness of implementation of each of the six areas of public policy in different countries (table). The medium values are in columns 2 and 3 of this table describes the intervals of change in the indicator values for most (68\%) countries.

\begin{tabular}{|c|c|c|}
\hline Infrastructure elements of business development & $\begin{array}{c}\text { Medium } \\
\text { values }\end{array}$ & $\begin{array}{c}\text { Typical for } \\
\text { most countries }\end{array}$ \\
\hline 1 & 2 & 3 \\
\hline 1. Knowledge and technology transfer & 4.39 & $3.43-5.35$ \\
\hline $\begin{array}{c}\text { infrastructure } \\
\text { 2. Commercial and professional } \\
\text { infrastructure }\end{array}$ & 5.46 & $4.68-6.24$ \\
\hline $\begin{array}{c}\text { 3. Production and information } \\
\text { infrastructure }\end{array}$ & 7.04 & $5.99-8 ., 09$ \\
\hline 4. Market infrastructure & 5.77 & $4.73-6,81$ \\
\hline $\begin{array}{c}\text { 5. Institutions that provide easy access to existing } \\
\text { markets }\end{array}$ & 4.71 & $3.89-5.53$ \\
\hline 6. Social and cultural infrastructure & 5.39 & $4.26-6.52$ \\
\hline
\end{tabular}

Table. Values of indicators that characterize the opinions of experts (on a ten-point scale)

Note: Achieved by the authors

According to the data from the table, experts from 54 countries considered that the highest level of development was characteristic of production and information infrastructure. The corresponding average value of the indicator on a ten-point scale exceeded 7. Average values from 5 to 6 units occurred in 2018 for such elements of the business infrastructure as market, commercial and professional infrastructure, as well as social and cultural infrastructure. The least developed elements in 2018 were, on average, institutions that provide easy access to existing markets, as well as knowledge and technology transfer infrastructure.

The average value of the indicator for knowledge and technology transfer infrastructure in 2018 was 4.39. The stage of this indicator more big than the upper limit of the interval (from 5.52 to 6.41) given in column 3 of the table was observed in such countries as Japan, Qatar, Taiwan, 
Indonesia, Luxembourg, the Netherlands, Switzerland, and Iran. These countries are located in Asia (Qatar, Japan, Taiwan, Indonesia, and Iran) and Europe (Luxembourg, the Netherlands, and Switzerland). They showed high (Luxembourg, the Netherlands, Switzerland, Japan, Qatar, Taiwan), medium (Iran) and low (Indonesia) incomes. Here and further, data on household income in 2018 were taken based on the data provided in the report on the Global entrepreneurship monitoring. Values of this indicator that are lower than the lower limit of the interval occurred in Mozambique, Morocco, Egypt, Angola, Saudi Arabia, Russia, Sudan and Cyprus. These countries are located in Asia (Saudi Arabia), Africa (Mozambique, Morocco, Egypt, Angola, and Sudan) and Europe (Russia, Cyprus). They had high (Saudi Arabia, Cyprus), medium (Russia) and low (Mozambique, Morocco, Egypt, Angola, Sudan) incomes.

The medium value of the index for commercial and professional infrastructure in the countries under review was 5.46. Maximum level of the index (from 6.29 to 6.77) was in following countries Taiwan, Qatar, China, Greece, Indonesia, Iran, Switzerland, the United States, Austria, Canada, the Netherlands. These countries are located in Asia (Taiwan, Qatar, China, Indonesia, and Iran), North America (Canada, USA) and Europe (Greece, Switzerland, Austria, and the Netherlands). They had high (Taiwan, Qatar, Canada, USA, Greece, Switzerland, Austria, the Netherlands), medium (China, Iran) and low (Indonesia) incomes. Low values (from 4.62 to 3.89) were observed in Mozambique, Ireland, Cyprus, Saudi Arabia, Chile, Panama and Peru. These countries are located in Latin America (Chile, Panama, and Peru), Africa (Mozambique), Asia (Saudi Arabia) and Europe (Cyprus, Ireland). They had high (Ireland, Cyprus, Panama, Chile, Saudi Arabia), medium (Peru) and low (Mozambique) incomes.

The medium value of the index for the production and information infrastructure of entrepreneurship in 54 countries was 7.04. Values of this indicator above the upper limit of the range (from 8.09 to 9.03) were observed in such countries as Chile, Japan, Colombia, Austria, Germany, the Netherlands, Switzerland, and Taiwan. These countries are located in Asia (Taiwan, Japan) Latin America (Chile, Colombia) and Europe (Austria, Germany, the Netherlands, and Switzerland). These countries (except Colombia) had high incomes. In Colombia and Indonesia, the income of the population was at an average level. Values lower than the lower limit of the range (from 5.99 to 4.37) were found in Lebanon, Angola, Puerto Rico, Madagascar, Mozambique, Israel, Sudan, and Italy. These countries are located in Latin America (Puerto Rico), Europe (Italy), Asia (Lebanon, Israel), and Africa (Madagascar, Mozambique, Sudan, and Angola). They had high (Puerto Rico, Italy, Israel), medium (Lebanon), and low (Madagascar, Mozambique, Sudan, and Angola) incomes. 
The medium value of the index describing the market infrastructure and the effectiveness of state programs for business development in the countries under review was 5.77 in 2018. Values of this indicator above the upper limit of the range (6.81) were observed in such countries as Turkey, Russia, Qatar, Indonesia, Iran, Colombia, Poland, Japan, South Korea, and Sudan. Six countries are located in Asia (Indonesia, Qatar, Turkey, Iran, Japan, and South Korea), two in Europe (Poland, Russia), one in Latin America (Colombia) and Africa (Sudan). There are countries characterized by high (Qatar, Japan, South Korea, Poland), medium (Turkey, values of the indicator less than the lower limit of the interval (from 4.73 to 4.14). Low indicators occurred in such countries as Uruguay, Luxembourg, India, Panama, Croatia, Canada, Israel, and Peru. They are located in Europe (Croatia, Luxembourg), Asia (India, Israel), North and Latin America (Canada, Uruguay, Peru, Canada, Uruguay, and Panama). These countries had high (Croatia, Luxembourg, Canada, Panama, Israel) and medium (Uruguay, Peru,) and low (India) incomes.

The medium value for the countries under review for institutions that provide easy access to existing markets was 4.71 . The highest values of the indicator (from 5.60 to 6.67) took place in 2018 in such countries as Israel, Greece, Luxembourg, Indonesia, Iran, the Netherlands, Qatar, Austria, Taiwan. These countries are located in Asia (Taiwan, Israel, Indonesia, Iran, Qatar) and Europe (Greece, Luxembourg, the Netherlands, Austria). They had high (Taiwan, Israel, Qatar, the Netherlands, Greece, Luxembourg, the Netherlands, Austria) and average (Iran) incomes. Values lower than the lower limits of the range (from 3.73 to 3.30) were observed in seven countries: Mozambique, Morocco, Cyprus, Madagascar, Russia, Sudan and Panama. They are located in Latin America (Panama), Africa (Mozambique, Morocco, Madagascar, and Sudan) and Europe (Russia, Cyprus). They had high (Panama, Cyprus), medium (Russia) and low (Mozambique, Morocco, Madagascar, Sudan) incomes.

The average value of the social and cultural infrastructure indicator for 54 countries was 5.30. Values above the upper limit of the interval (from 6, 69 to 8.08) was noted in countries such as Colombia, UAE, Netherlands, Iran, Qatar, Lebanon, China, USA. These countries are located in Asia (UAE, Iran, Lebanon, Qatar, and China), North and Latin America (USA, Colombia) and Europe (Netherlands). They had high (USA, Netherlands, Qatar, UAE), average (Iran, Lebanon, Colombia, China) incomes of the population. Values lower than the lower limit of the interval (from 4.21 to 3.05) were found in Mozambique, Slovakia, Cyprus, Brazil, Bulgaria, Uruguay, Italy, Japan, Slovenia and Madagascar. These countries are located in Europe (Bulgaria, Italy, Slovakia, Slovenia, and Cyprus), Asia (Japan), Latin America (Brazil, Uruguay) and Africa (Mozambique, Madagascar). They had high (Italy, Slovakia, Slovenia, Cyprus, Japan), medium (Brazil, Uruguay, Bulgaria) and low (Mozambique, Madagascar) incomes. 
Information demonstrated in column three of the table indicated considerable contrast of the level six indexes by country. That is why hypothesis 1 was affirmed. The analyzing of the roster of countries with maximum and minimum level for the six indexes demonstrates that relationship between territorial position and incomes of population in the countries does not confirmed. So we can make outcome on confirming hypotheses two and three.

\section{Conclusion}

The research has achieved its goal. Novelty and originality of our study include:

- the medium level index and their intervals of change describing the ten-point scale of experts' opinions on the effectiveness of business development infrastructure were determined for most countries.

- the countries with maximum and minimum values for six indexes were calculated.

- it is demonstrated that the highest medium value for countries is marked by an indicator that, according to experts, characterizes the efficiency of production and information infrastructure.

- it is proved that the lowest medium value for countries is typical for such an indicator as the efficiency of knowledge and technology transfer infrastructure.

- it is shown that the values of each of the six indicators under consideration are significantly differentiated across 54 countries.

- relationship between maximum and minimum indexes values and territorial position and incomes of population in the countries did not confirmed.

The calculated mathematical models can be consumed in following research. The revealed new information can be applied in the pedagogical work of universities. Results of research are of interest for the state management in the formation and realization of development of the entrepreneurship.

Further research may be related to the study of the effectiveness of the implementation of six elements of the enterprise development infrastructure according to the Global entrepreneurship monitoring project in the following years. 


\section{Bibliographic References}

ALVAREZ, Claudia; URBANO, David; CODURAS, Alicia; RUIZ-NAVARRO, Jose. 2011. "Environmental Conditions and Entrepreneurial Activity: A Regional Comparison in Spain" In: Journal of Small Business and Enterprise Development. Vol. 18, No. 1, pp. 120-140.

CALDERON, Cesar; SERVEN, Luis. 2004. The Effects of Infrastructure Development on Growth and Income Distribution. Working Papers Central Bank of Chile 270. Central Bank of Chile.

GAGANIS, Chrysovalantis; PASIOURAS, Fotios; VOULGARI, Fotini. 2018. "Culture, business environment and SMEs' profitability: Evidence from European Countries” In: Economic Modelling. Vol. 78, pp. 275-292.

GARE, Klas; MELIN, Ulf. 2011. "SMEs need formative infrastructure for business transformation" In: Journal of Enterprise Information Management. Vol. 24, No. 6, pp. 520-533.

GLOBAL ENTREPRENEURSHIP MONITOR 2018-2019. 2019. Bosma N., Kelley D. and the Global Entrepreneurship Research Association (GERA). 152 p. Available online. In: https://www.gemconsortium.org/ file/open?fileId=50213. Consultation date: $05 / 03 / 2020$.

GUNSEL, Ayşe. 2015. "Research on Effectiveness of Technology Transfer from a Knowledge Based Perspective" In: Procedia - Social and Behavioral Sciences. Vol. 207, pp. 777-785.

DECKER, Ryan; HALTIWANGER, John; JARMIN, Ron; MIRANDA, Javier. 2014. "The Role of Entrepreneurship in US Job Creation and Economic Dynamism” In: Journal of Economic Perspectives. Vol. 28, No. 3, pp. 3-24.

DE CAROLIS, Donna Marie; SAPARITO, P. 2006. "Social capital, cognition, and entrepreneurial opportunities: a theoretical framework" In: Entrepreneurship Theory and Practice. Vol. 30, No. 1, pp. 41-56.

DICKERHOF, Markus. 2010. "A Cooperation Model and Demand-Oriented ICT Infrastructure for SME Development and Production Networks in the Field of Microsystem Technology. Svetan Ratchev" In: Precision Assembly Technologies and Systems. Vol. 315, pp. 319-328.

INFODEV. 2010. Global Good Practice in Incubation Policy Development and Implementation. The World Bank. Washington, DC. USA.

KEMP, Ron; MOSSELMAN, Marco; BLEES, Jasper; MAAS, Jeroen. 2003. Barriers to Entry. Scales Research Reports H200301. EIM Business and Policy Research. Zoetermeer. 
KISELEVA, Olga; LEBEDEV, Anton; PINKOVETSKAIA, Iuliia; ROJASBAHAMÓN, Magda; ARBELÁEZ CAMPILLO, Diego. 2019. "Specialization and concentration of small and medium enterprises employees: Russian data” In: Amazonia Investiga. Vol. 8, No. 20, pp. 6-15. Available online. In: https://amazoniainvestiga.info/index.php/ amazonia/article/view/59. Consultation date: 05/03/2020.

OBOKOH, Lawrence; GOLDMAN, Geoff. 2016. "Infrastructure deficiency and the performance of small- and medium-sized enterprises in Nigeria's Liberalised Economy. Acta Commercii” In: Independent Research Journal in the Management Sciences. Vol. 16, No. 1, pp. 1-10.

PANAYOTIS, Kotsios. 2010. Regulatory Barriers to Entry in Industrial Sectors. MPRA Paper 27976. University Library of Munich. Munich, Germany.

PINKOVETSKAIA, Iuliia S. 2015. "Modeling of indicators of small and mediumsized businesses in the regions using the density function of normal distribution" In: Problems of territory development. Vol. 6, No. 8o, pp. 93-107.

PINKOVETSKAIA, Iuliia; ARBELAEZ CAMPILLO, Diego Felipe; ROJASBAHAMÓN, Magda Julissa; GROMOVA, Tatiana; NIKITINA, Irina. 2019. "Female entrepreneurship development in the Russian Federation" In: Amazonia Investiga. Vol. 8, No. 18, pp. 111-118. Available online. In: https://amazoniainvestiga.info/index.php/amazonia/article/view/287. Consultation date: 05/03/2020.

PINKOVETSKAIA, Iuliia; LYUBOVTSEVA, E; ARBELÁEZ-CAMPILLO, Diego; ROJAS-BAHAMÓN, Magda. 2020. "Small and medium enterprises in Russia and other countries" In: Amazonia Investiga. Vol. 9, No. 25, pp. 99-106. Available online. In: https://amazoniainvestiga.info/index.php/ amazonia/article/view/1034. Consultation date: 15/06/2020.

ROBINSON, Sherri; STUBBERUD, Hans Anton. 2014. "Business incubators: What services do business owners really use?” In: International Journal of Entrepreneurship. Vol. 18, pp 29-39.

SIMON-MOYA, Virginia; REVUELTO-TABOADA, Lorenzo; RIBEIROSORIANO, Domingo. 2016. "Influence of economic crisis on new SME survival: reality or fiction?” In: Entrepreneurship and Regional Development. Vol. 28, No. 1-2, pp. 157-176.

SUNG, Tae Kyung. 2002. "Knowledge and technology transfer in technoparks development" In: International Journal of Technology Policy and Management. Vol. 2, No. 3, pp. 240-259.

VANDENBERG, Paul; CHANTAPACDEPONG, Pornpinun; YOSHINO, Naoyuki. 2016. SMEs in Developing Asia New Approaches to Overcoming Market Failures. Asian Development Bank Institute, Tokyo, Japan. 

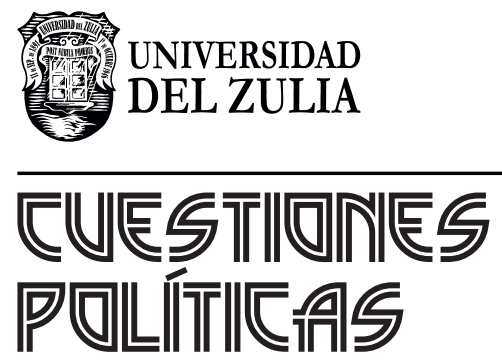

Vol.39 No 68

Esta revista fue editada en formato digital y publicada en enero de 2021, por el Fondo Editorial Serbiluz, Universidad del Zulia. Maracaibo-Venezuela 